\section{Annales de la Faculté de Droit d'Istanbul}

\title{
Drone Attacks and the Principle of Proportionality in the Law of Armed Conflict
}

\author{
Siha Saldırıları ve Silahlı Çatışma Hukukunda Orantılııı illkesi
}

\section{Yunus Emre Gül ${ }^{\star}$}

\begin{abstract}
Technology has developed significantly in the past few decades; obligations on belligerent parties, however, have not changed. One of these obligations is to respect the principle of proportionality while conducting attacks against lawful targets. For this reason, whilst military advantage can be gained through drone attacks, those attacks must not result in excessive harm inflicted upon civilian lives and properties. Also, belligerent parties should take all feasible precautions in order to minimize collateral damage and always take Human Rights Law into consideration even if the particular drone attack is lawful according to the Law of Armed Conflict.
\end{abstract}

\section{Keywords}

Law of Armed Conflict, principle of proportionality, drone attacks, excessive, collateral damage

Öz

Teknoloji, son birkaç on yılda önemli ölçüde gelişti, ancak savaşan tarafların yükümlülükleri değişmedi. Bu yükümlülüklerden biri de meşru hedeflere yönelik saldırılar düzenlerken orantılılık ilkesine riayet etmektir. Bu nedenle her ne kadar askeri avantajın SiHA saldırıları ile kazanılması mümkün olsa da bu saldırılar sonucu sivillerin canlarına ve mallarına yönelik aşırı zararlara yol açılmamalıdır. Ayrıca savaşan taraflar, tali zararı en aza indirebilmek için mümkün olan bütün önlemleri almalı ve belirli bir SiHA saldırısı her ne kadar Silahlı Çatışma Hukuku'na uygun olsa da İnsan Hakları Hukuku'nu da her zaman dikkate almalıdırlar.

\section{Anahtar Kelimeler}

Silahlı Çatışma Hukuku, orantılııı ilkesi, SiHA saldırıları, aşırı, tali hasar

\footnotetext{
* Corresponding Author: Yunus Emre Gül (LLM), King's College London, Law School, London, UK. E-mail: yunus_emre.gul@kcl.ac.uk ORCID: 0000-0002-8701-2236
}

To cite this article: Gul YE, "Drone Attacks and the Principle of Proportionality in the Law of Armed Conflict", (2021) 70 Annales de la Faculté de Droit d'Istanbul 119. https://doi.org/10.26650/annales.2021.70.0005 


\section{Drone Attacks and the Principle of Proportionality in the Law of Armed Conflict}

\section{Introduction}

The root of remote-control machines dates back to Second World War. The 'Goliath', German remote-controlled vehicle was used during the war in order to destroy tanks, disrupt dense infantry formations, and demolish buildings and bridges. ${ }^{1}$ Also, another type of remote-controlled vehicle, the Teletank, was used by the Soviet Union to destroy enemy fortifications and bunkers. ${ }^{2}$ Although these remote technologies were in use in land combat, the idea of using armed drones in air warfare goes back to 1970 s, but it became reality in 2001 through the use of drones by the USA against al-Qaida members in the eastern Afghan city of Jalalabad. ${ }^{3}$

Even though different terminologies are used in the doctrine such as unmanned aerial vehicle (UAV) or remotely piloted aircraft (RPA), these terms can be classified under the general term 'drone', or 'an aircraft that, whilst it does not carry a human operator, is flown remotely by a pilot, is normally recoverable, and can carry a lethal or non-lethal payload'. ${ }^{4}$ Drones which carry lethal payloads can be called 'armed drones.' Alternatively, it is defined in the HPRC Manual on International Law Applicable to Air and Missile Warfare as 'unmanned military aircraft of any size which carries and launches a weapon, or which can use on-board technology to direct such a weapon to a target'. ${ }^{5}$ In the scope of this essay, attacks carried out by those types of drones will be examined.

Military drones are currently used by ninety-five countries, and they have been used by at least twenty-eight countries outside of their borders since the 1980s. ${ }^{6}$ However, armed drones started to catch international society's attention after alQaeda operative Ali Qaed Senyan al-Harithi was killed by a predator drone in Yemen by the CIA in $2002 .^{7}$ After that, use of drones by states was significantly boosted, and although 21,000 of them are confirmed officially, it is estimated that the actual

1 E. W. Powers, 'Developing and Integrating Unmanned Systems for Military Operations' in Ronan Doaré and others (eds), Robots on the Battlefield Contemporary Perspectives and Implications for the Future (Combat Studies Institute Press 2014) 201.

2 ibid.

3 Mary Ellen O'Connell, 'Unlawful Killing with Combat Drones: A Case Study of Pakistan, 2004-2009' (Social Science Research Network 2009) 3 <https://papers.ssrn.com/abstract=1501144> accessed 5 May 2020."plainCitation":"Mary Ellen O’Connell, 'Unlawful Killing with Combat Drones: A Case Study of Pakistan, 2004-2009' (Social Science Research Network 2009

4 UK Ministry of Defence, Unmanned Aircraft Systems (Development, Concepts and Doctrine Centre 2017) 12.

5 Program on Humanitarian Policy and Conflict Research at Harvard University, HPCR Manual on International Law Applicable to Air and Missile Warfare (Bern, 15 May 2009) ('HPRC Manual') art 1(ee).

6 Dan Gettinger, The Drone Databook (The Center for the Study of the Drone at Bard College 2019) XII.

7 Michael N Schmitt, 'Drone Attacks under the Jus Ad Bellum And Jus in Bello: Clearing the "Fog of Law"' in MN Schmitt, Louise Arimatsu and T McCormack (eds), Yearbook of International Humanitarian Law - 2010, vol 13 (T M C Asser Press 2011) 2. 
number exceeds $30,000 .{ }^{8}$ They are also used by non-state actors; however, this essay will only deal with state practices.

As stated in article 35(1) of Additional Protocol I (AP-I), '[i]n any armed conflict, the right of the Parties to the conflict to choose methods or means of warfare is not unlimited.' ${ }^{\prime}$ In other words, which means of warfare can be used in combat by states and how to use them are subject to certain principles of the Law of Armed Conflict (LOAC). One of those principles is the proportionality which prohibits attacks that 'may be expected to cause incidental loss of civilian life, injury to civilians, damage to civilian objects, or a combination thereof, which would be excessive in relation to the concrete and direct military advantage anticipated.' ${ }^{10}$ Thus, the principle of proportionality balances two values, expected civilian damage and anticipated military advantage. This balance should also be protected when carrying out drone strikes in armed conflicts.

In the first part of this article the laws regulating drone attacks, which are Law of Armed Conflict (LOAC) and International Human Rights Law (IHRL), will be examined. Although the LOAC is applicable in times of armed conflicts as lex specialis, this does not preclude to fulfil human rights obligations of states. Since drones are especially used outside of the borders of attacking states, these states still must respect those obligations in the territory where they have control. In the second part, the regulation of the principle of proportionality in the LOAC and how it can be applied to drone attacks will be explained. Although drones promise a significant advantage to attacking parties, they also bring some problems regarding proportionality, a review of which will be determined in this article.

\section{The Law Regulating Drone-Attacks in Armed Conflicts}

\subsection{The Legality of Using Armed Drones under the LOAC}

After French military forces used the balloon 'Entreprenant' against Austrian forces at the Battle of Fleurus (1794), air warfare occurred as a new type of warfare. ${ }^{11}$ However, regulating this new type of warfare succeeded more than a hundred years later at Hague Peace Conference (1899), and 'the launching of projectiles and explosives from balloons, or by other new methods of a similar nature' was prohibited for 5 years. ${ }^{12}$ However, after World War I (WWI), the contribution of air power to

8 Gettinger (n 6) IX.

9 Protocol Additional to the Geneva Conventions of 12 August 1949, and relating to the Protection of Victims of International Armed Conflicts (adopted 8 June 1977, entered into force 7 December 1978) 1125 UNTS 3 ('AP-I').

10 AP-I art. 51(5)(b). Also see AP-I art. 57(2)(a)(iii) and 57(2)(b).

11 Michael N Schmitt, 'Air Warfare' in Andrew Clapham and Paola Gaeta (eds), The Oxford Handbook of International Law in Armed Conflict (Online 2014) 2.

12 'Declaration (IV,1), to Prohibit, for the Term of Five Years, the Launching of Projectiles and Explosives from Balloons, and Other Methods of Similar Nature. The Hague, 29 July 1899.' <https://ihl-databases.icrc.org/applic/ihl/ihl.nsf/Article. xsp?action=openDocument\&documentId=C372920FFD61039AC12563CD00516126 $>$ accessed 30 January 2020. 
warfare was well-understood, and it is not wrong to say that the victory of World War II (WWII) was determined by air warfare.

International society always has an interest towards new technologies and using them during armed conflicts because of their advantages, such as harming enemies without risking the armed forces of states. However, as mentioned above, article 35 of the AP-I imposes two burdens upon the parties of an armed conflict. First, they need to check the legality of using new weapon, and second, even if it is legal, they need to use it in accordance with the principles of the LOAC.

Although the answer is obvious, it should be clarified whether drones are a new type of 'weapon' or not. The term 'weapon' is defined in the HPRC Manual as 'a means of warfare used in combat operations, including a gun, missile, bomb or other munitions, that is capable of causing either (i) injury to, or death of, persons; or (ii) damage to, or destruction of, objects. ${ }^{13}$ There is no doubt that armed drones can cause such consequences, and if they are used during armed conflicts, they will be subject to rules regarding weapons regulated in the LOAC.

According to AP-I art. 36, '[i]n the study, development, acquisition or adoption of a new weapon, means, or method of warfare, a High Contracting Party is under an obligation to determine whether its employment would, in some or all circumstances, be prohibited by this Protocol or by any other rule of international law applicable to the High Contracting Party'. For this reason, before using a new weapon or method, such as cyber means or drones, belligerent parties should review its legality under the LOAC. Hence, three principles of the LOAC are significant: the Principle of Distinction, the Principle of Proportionality, and the Principle of Precautions. As the ICJ stated in the Nuclear Weapons Advisory Opinion, these principles apply to 'all forms of warfare and to al1 kinds of weapons, those of the past, those of the present, and those of the future'. ${ }^{14}$

Two issues in the law of weapons should be distinguished from each other: first, weapons that are unlawful per se under customary international law because of their nature of causing superfluous injury or unnecessary suffering, such as chemical or biological weapons, or of being indiscriminate and second, using a lawful weapon system in an unlawful manner, such as the usage of SCUD missiles by the Iraqi army in the 1990-91 Gulf War against cities without taking civilian casualties into consideration. ${ }^{15}$ From that perspective, although drones are not illegal per se due to their nature, it is possible to use them in an unlawful manner by violating principles which are stated above.

13 HPRC Manual Article 1(ff)

14 Legality of the Threat or Use of Nuclear Weapons (Advisory Opinion) [1996] (hereinafter 'Nuclear Weapons') ICJ Rep para. 86.

15 Michael N Schmitt and Jeffrey S Thurnher, 'Out of the Loop: Autonomous Weapon Systems and the Law of Armed Conflict' (2013) 4 Harvard National Security Journal 231, $243 \mathrm{ff}$. 
Two criticisms have been raised on the issue of conducting attacks via drones: attacking belligerents without 'human eyes on the target' and the causation of a 'PlayStation mentality to killing. ${ }^{16}$ Schmitt answers these in the following manner: First, drone attacks are based on high resolution imagery, and if it is necessary, monitoring a target for a long time is possible. ${ }^{17}$ Therefore, from his perspective, conducting attacks without 'human eyes on the target' does not make any difference. On the 'PlayStation mentality to killing,' he states that the focal point is not the 'mental attitude of the attacker' but identifying lawful targets correctly and preventing collateral damage as much as possible. ${ }^{18}$ Nevertheless, states still need to provide 'training programs for drone operators who have never been subjected to the risks and rigors of battle to instil respect for IHL and adequate safeguards for compliance with it' in order to prevent comfortable killings and excessive civilian damage. ${ }^{19}$

\subsection{Drone attacks and the LOAC}

Drone attacks which are conducted in an armed conflict will be subject to the LOAC as lex specialis. It is stated in the Tadic Case that 'an armed conflict exists whenever there is a resort to armed force between States or protracted armed violence between governmental authorities and organized armed groups or between such groups within a State. ${ }^{20}$ In line with this definition, there are two types of armed conflicts: international and non-international, and the difference between these two types of armed conflicts is the status of the actors, which will be explained below.

An international armed conflict arises when there is a resort to armed force between two or more states as defined in the Tadic Case and Common Article 2 of the Geneva Conventions. Therefore, there must be at least one state on either side of the conflict or an armed group whose acts are attributable to a state. While the 'overall control' test is applied by the International Criminal Tribunal for the former Yugoslavia (ICTY) in the Tadic Case in order to determine the relationship between a state and an armed group ${ }^{21}$, the International Court of Justice (ICJ) rejects this notion and adopts a stricter criterion, namely 'effective control. ${ }^{22}$ Lastly, if the war is declared by one state against another, the LOAC applies even if they have not resorted to armed force yet.

16 Schmitt (n 7) 8-9.

17 ibid 8.

18 ibid 9.

19 UNHRC, Report of the Special Rapporteur on Extrajudicial, Summary or Arbitrary Executions, Philip Alston, Addendum, Study on Targeted Killings, UN Doc. A/HRC/ 14/24/Add.6, (May 28, 2010) (hereinafter 'UN Doc. A/HRC/ 14/24/Add.6') para. 84.

20 Prosecutor v Dusko Tadic (Decision on the Defence Motion for Interlocutory Appeal on Jurisdiction) ICTY-94-1 (2 October 1995) para 70.

21 Prosecutor v Dusko Tadic (Appeal Judgement) ICTY-94-1-A (15 July 1999) para 145.

22 Military and Paramilitary Activities in and against Nicaragua (Nicaragua v. United States of America) (Judgment) [1984] ICJ Rep para 115. 
Common Article 3 regulates non-international armed conflicts by defining them as an armed conflict which is 'not of an international character occurring in the territory of one of the High Contracting Parties.' However, the occurrence of non-international armed conflict is dependent on two criteria according the Tadic Case, which are intensity and organization. ${ }^{23}$ Protracted armed violence indicates a threshold of intensity which is higher than 'isolated or sporadic acts of violence.' ${ }^{24}$ Also, an armed group which has 'a set of structures or mechanisms, whatever those may be, that are sufficiently efficient to ensure the coordination necessary to carry out an attack directed against a civilian population' and 'sufficient means to promote or encourage the attack,' meets the organization criterion. ${ }^{25}$ However, both criteria should be determined on a case by case basis.

After the type of armed conflict is determined, all acts which are related to the armed conflict will be governed by the LOAC. ${ }^{26}$ Hence, belligerent parties must always respect the principles of the LOAC while conducting drone attacks in both international and non-international armed conflicts. Although there is no clear regulation in either the Geneva Conventions nor the Additional Protocols on the application of proportionality to non-international armed conflicts, this issue will be clarified under 2.1. of this article.

\subsection{Applicability of Human Rights Law to Extraterritorial Drone Attacks in War Times}

The application of the LOAC as lex specialis does not prevent applying the Human Rights Law during armed conflicts. The nexus between these two branches of law is discussed in the Nuclear Weapons Advisory Opinion, and the ICJ argued that the International Covenant on Civil and Political Rights is applied in an armed conflict; however, the prohibition of the arbitrary deprivation of life is determined in accordance with the LOAC, which governs the armed conflict as lex specialis. ${ }^{27}$ This approach is reiterated by the ICJ in The Wall Advisory Opinion ${ }^{28}$ and the Armed Activities Judgement. ${ }^{29}$ Nonetheless, the Court also added in the former decision that

23 Prosecutor v Dusko Tadic (Judgment) ICTY-94-1-T (7 May 1997) (Tadic Trial Judgement) para 562; Prosecutor v Jean-Paul Akayesu (Trial Judgment) ICTR-96-4-T (2 September 1998) para 620; Jean S Pictet (ed), Commentary I Geneva Convention For the Amelioration of the Condition of the Wounded and Sick in Armed Forces in the Field (ICRC 1952) 49-50.

24 Tadic Trial Judgement (n 13) para 562; Prosecutor v Jean-Pierre Bemba Gombo (Judgment pursuant to Article 74 of the Statute) ICC-01/05-01/08 (21 March 2016) para 140.

25 Prosecutor v Germain Katanga (Judgement pursuant to article 74 of the Statute) ICC- 01/04-01/07 (7 March 2014) para 1119.

26 Prosecutor v Dragoljub Kunarac, Radomir Kovac and Zoran Vukovic (Judgement) ICTY-96-23 \& ICTY-96-23/1-A (12 June 2002) para 57; Nils Melzer, Human Rights Implications of the Usage of Drones and Unmanned Robots in Warfare (European Parliament 2013) 21.

27 Nuclear Weapons Advisory Opinion para. 25

28 Legal Consequences of the Construction of a Wall in the Occupied Palestinian Territory (Advisory Opinion) [2004] (hereinafter 'The Wall') ICJ Rep para. 106.

29 Case Concerning Armed Activities on the Territory of the Congo (Democratic Republic of the Congo v. Uganda) (Judgment) [2005] (hereinafter 'Armed Activities') ICJ Rep para. 216 ff. 
'some rights may be exclusively matters of international humanitarian law; others may be exclusively matters of human rights law; yet others may be matters of both these branches of international law' in armed conflicts. ${ }^{30}$ Therefore, IHRL may be applied 'in parallel' with the LOAC at the same time, and states, which conduct drone attacks specifically against non-state actors, must take human rights treaties, whose jurisdiction are recognized by them, into consideration in the case of armed conflict. ${ }^{31}$

The application of human rights treaties during an armed conflict can be claimed by all people who are under the jurisdiction of a state that is party to the treaty. However, the jurisdiction of a state should not be interpreted within national boundaries. As it is stated by the Inter-American Commission in the Alejandre Case, 'when agents of a state, whether military or civilian, exercise power and authority over persons outside national territory, the state's obligation to respect human rights continues. ${ }^{32}$ Hence, if the authority of a state is established over a person or territory, it will be possible to apply human rights treaties, and the applicable test provided by the European Court of Human Rights is 'effective control.'33

Human rights treaties apply extraterritorially not only when there is an effective control over a land but also in the case of control over facilities and persons. As stated in the Al Sadoon Case, after control is established over a detention facility, detainees will be under the jurisdiction of a controlling state. ${ }^{34}$ Even if the facility is controlled by a state but another state implements control over a detainee, the jurisdiction of the latter is established. As decided in Hassan v. UK, while control over a facility, Camp Bucca, is implemented by the US, the jurisdiction of the UK was established because of its control over a particular person. ${ }^{35}$

Last but not least, an act can constitute the breach of the International Human Rights Law in spite of its legality under the LOAC, and it may create a responsibility of the state. As stated by the ICJ,

'There can be no doubt that, as a general rule, a particular act may be perfectly lawful under one body of legal rules and unlawful under another. Thus, it cannot be excluded in principle that an act carried out during an armed conflict and lawful under international humanitarian law can at the same time constitute a violation by the State in question of some other international obligation incumbent upon it' ${ }^{36}$

30 The Wall Advisory Opinion para. 106.

31 Silvia Borelli, 'The (Mis)-Use of General Principles of Law: Lex Specialis and the Relationship Between International Human Rights Law and the Laws of Armed Conflict' in Laura Pineschi (ed), General Principles of Law-The Role of the Judiciary (Springer 2015) 273; Armed Activities Judgement para 216; Hassan v United Kingdom App no 29750/09 (ECtHR 16 September 2014) (hereinafter 'Hassan v. UK') para 77.

32 Alejandre et al. v Cuba Case No. 11.589 (IACiHR 29 September 1999) para 25.

33 Bankovic and others $v$ Belgium and 16 other Contracting States App No. 52207/99 (ECtHR 12 December 2001) paras 74-82; Loizidou v Turkey App no. 15318/89 (ECtHR 23 March 1995) paras 59-64.

34 Al-Saadoon and Mufdhi $v$ The United Kingdom App no. 61498/08 (ECtHR 30 June 2009) para 88.

35 Hassan v. UK para 80

36 Application of the Convention on the Prevention and Punishment of the Crime of Genocide (Croatia v. Serbia) (Judgment) [2015] ICJ Rep para 474. 
Therefore, even if a military operation pursues a legitimate aim, it must be 'planned and executed with the requisite care for the lives of the civilian population. ${ }^{37}$ Hence, belligerent parties must conduct drone attacks by taking all feasible precautions in order to minimize civilian harm even if the attack is lawful according to the LOAC.

\section{The Principle of Proportionality and Its Application to Drone Attacks}

\subsection{The Principle of Proportionality in the LOAC}

In the Second World War, General Douglas MacArthur preferred a land attack rather than air bombardment in order to avoid a few thousand civilian casualties in Manila, but when the attack was over, it became apparent that while 16,000 Japanese and 1,000 American soldiers died in the conflict, 100,000 civilians were killed specifically because of the exchange of fire between American and Japanese forces. ${ }^{38}$ The principle of proportionality in armed conflicts gained importance after such incidents occurred in WWII. Although war always carries risk to civilian lives and property, to inflict such risks on them must be determined carefully.

The principle of proportionality in the LOAC stipulates that collateral damage inflicted on civilian persons and properties must be proportionate, and the foreseeable damage to civilians must not be 'excessive' when compared to the expected military advantage of the attack. While proportionality could not be defined clearly until the preparation of the Additional Protocols to the Geneva Conventions, some footwork can be found much earlier. According to Article 15 of the Lieber Code (1863), 'all direct destruction of life or limb of 'armed' enemies, and of other persons whose destruction is incidentally 'unavoidable' in the armed contests of the war' were permitted within the context of military necessity. ${ }^{39}$ Also, it was stated in the Hague Rules of Air Warfare (1923) that military concentration should be sufficiently important for the bombing of cities, settlements, and buildings in the immediate vicinity of military operations in order to justify the danger to which the civilian population will be exposed due to this. ${ }^{40}$ Although both articles neither clearly define proportionality nor are binding, they are important clues to understand the current form of that principle.

The first binding articles on the principle of proportionality were brought by AP-I. According to article 51(5)(b) of the Protocol, 'an attack which may be expected to cause incidental loss of civilian life, injury to civilians, damage to civilian objects,

37 Isayeva v Russia App no 57950/00 (ECtHR 24 February 2005) para 200.

38 William J Fenrick, 'The Rule of Proportionality and Protocol I in Conventional Warfare' (1982) 98 Military Law Review 91, 91-92.

39 Instructions for the Government of Armies of the United States in the Field (24 April 1863) ('Lieber Code').

40 Rules concerning the Control of Wireless Telegraphy in Time of War and Air Warfare (December 1922 - February 1923) ('1923 Hague Rules of Air Warfare') 
or a combination thereof, which would be excessive in relation to the concrete and direct military advantage anticipated' is accepted as 'indiscriminate' and, therefore, prohibited. Other important regulations are articles 57(2)(a)(iii) and 57(2)(b) of the same protocol. ${ }^{41}$ While the former regulates those attacks at the planning stage, the latter governs the execution stage, yet both articles similarly prohibit those attacks which would cause excessive damage if this damage is obvious whether the attack is being planned or carried out. Consequently, there must be four cumulative factors in order to determine whether the specific attack is indiscriminate or not. First, there must be an 'attack.' Second, the attack must cause 'damage.' Third, this damage must reach a certain level of intensity which is defined as loss of civilian life, injury to civilians, and/or damage to civilian objects. Fourth, this damage must be 'excessive' when compared to the anticipated military advantage.

On the other hand, while AP-I, which is applicable to international armed conflicts, includes regulations on proportionality, Additional Protocol II (AP-II) ${ }^{42}$, which is applicable to non-international armed conflicts, does not contain any explicit reference to it. First, however, it is stated in the work of the ICRC, which clarifies customary rules of armed conflicts, that the principle of proportionality is customary in nature for both international and non-international armed conflicts by referencing state practices. ${ }^{43}$ Secondly, the principle of humanity expressed in the preamble of AP-II inherently includes the principle of proportionality, and belligerent parties must always respect it. ${ }^{44}$ Third, Amended Protocol II to the Convention of Certain Conventional Weapons ${ }^{45}$, which is applicable in non-international armed conflicts as a recent treaty, prohibits civilian damage 'which would be excessive in relation to the concrete and direct military advantage anticipated. ${ }^{\prime 46}$ Fourth, the applicability of the principle to this type of conflict is approved and applied by International Tribunals. ${ }^{47}$

41 It is stated in those provisions of Article 57(2) that

'(a) those who plan or decide upon an attack shall:

(iii) refrain from deciding to launch any attack which may be expected to cause incidental loss of civilian life, injury to civilians, damage to civilian objects, or a combination thereof, which would be excessive in relation to the concrete and direct military advantage anticipated;

(b) an attack shall be cancelled or suspended if it becomes apparent that the objective is not a military one or is subject to special protection or that the attack may be expected to cause incidental loss of civilian life, injury to civilians, damage to civilian objects, or a combination thereof, which would be excessive in relation to the concrete and direct military advantage anticipated'.

42 Protocol Additional to the Geneva Conventions of 12 August 1949 and relating to the Protection of Victims of NonInternational Armed Conflicts (adopted 8 June 1977, entered into force 7 December 1978) 1125 UNTS 609 ('AP-II').

43 Jean-Marie Henckaerts and Louise Doswald-Beck (eds), Customary International Humanitarian Law (Cambridge University Press 2005) 48.

44 ibid. Also see Prosecutor v Zoran Kupreskic and others (Judgement) ICTY-95-16-T (14 January 2000) (Kupreskic Trial Judgement) para 524.

45 Protocol on Prohibitions or Restrictions on the Use of Mines, Booby-Traps and Other Devices (entered into force 2 December 1983) 1342 UNTS 168, 19 ILM 1529, as amended 3 May 1996, 35 ILM 1206 ('Amended Mines Protocol'), Article 1(3).

46 Amended Mines Protocol art 3(8)(c); Henckaerts and Doswald-Beck (n 43 ) 48.

47 Kupreskic Trial Judgement (n 30) para 524. 


\subsection{The Application of the Principle of Proportionality to Drone Attacks}

\subsubsection{Categories of Lawful Targets}

The operator should always respect the principle of proportionality while conducting a drone strike. Although carrying out direct attacks against civilian persons or properties are strictly prohibited in the LOAC, the principle of proportionality regulates attacks that aim to hit lawful targets but causes unintentional damages to civilian people and property. Hence, it is not related to which things can be attacked but has relevance with how an attack can be conducted against lawful targets. ${ }^{48}$

There are different categories of people who are lawful targets according to the LOAC. The first category is combatants who are subject to direct attack of an enemy. Combatants are members of the armed forces who have a right to participate directly in hostilities. ${ }^{49}$ While they are lawful targets, if they are captured by an enemy, they have a right to be a prisoner of war and do not bear any responsibility arising out of their lawful conduct. ${ }^{50}$ The second category consists of civilians who directly participate in hostilities. A person is accepted as a lawful target if he/she meets three cumulative criteria which are threshold of harm, direct causation, and belligerent nexus. ${ }^{51}$ They are lawful targets 'for such time as they take a direct part in hostilities, ${ }^{52}$ and if they are captured, they cannot be a prisoner of war. The third category, although there is a discussion on it, consists of members of an organized armed group which is a belligerent party in an armed conflict. They are 'individuals whose continuous function involves the preparation, execution, or command of acts or operations amounting to direct participation in hostilities. ${ }^{53}$ At first glance, the second and third category may seem identical, but the difference is that while civilians who fall in the former category 'directly participate in hostilities on a merely spontaneous, sporadic, or unorganized basis,' the latter category of people has continuous combat function which 'requires lasting integration into an organized armed group acting as the armed forces of a non-state party to an armed conflict. ${ }^{54}$ The result of this distinction is that

48 FJ Hampson, 'The Principle of Proportionality in the Law of Armed Conflict' in S Perrigo and J Whitman (eds), The Geneva Conventions Under Assault (Pluto Press 2010) 46.

49 AP-I art 43(2).

50 AP-I art 44(1).

51 These criteria are defined in Interpretive Guidance on the Notion of Direct Participation in Hostilities by ICRC as; ' 1 . the act must be likely to adversely affect the military operations or military capacity of a party to an armed conflict or, alternatively, to inflict death, injury, or destruction on persons or objects protected against direct attack (threshold of harm), and

2. there must be a direct causal link between the act and the harm likely to result either from that act, or from a coordinated military operation of which that act constitutes an integral part (direct causation), and

3. the act must be specifically designed to directly cause the required threshold of harm in support of a party to the conflict and to the detriment of another (belligerent nexus).' See Nils Melzer, Interpretive Guidance on the Notion of Direct Participation in Hostilities under International Humanitarian Law (International Committee of the Red Cross 2009) 46.

52 AP-I art 51(3); AP-II art 13(3).

53 Melzer (n 51) 34.

54 ibid. 
'Civilians lose protection against direct attack for the duration of each specific act amounting to direct participation in hostilities whereas members of organized armed groups belonging to a non-state party to an armed conflict cease to be civilians and lose protection against direct attack, for as long as they assume their continuous combat function. ${ }^{55}$

In other words, those who directly participate in hostilities lose their protected status only for a limited period of time, but the last category of persons loses it 'as long as they remain members,' and this membership results in rendering them as lawful targets 'even before he or she first carries out a hostile act.' ${ }^{56}$ At this point, it is a well-known fact that some terrorist organisations deliberately mix their members within a civilian population to prevent being targeted by states. ${ }^{57}$ Even though it is hard to distinguish those members from the civilian population, the responsibility of the attacker is limited to intelligence available to him/her at the time of an attack. However, if there is a difference in terms of intelligence reports between a drone operator and a commander on the ground, it is the duty of the pilot 'to ensure that a commander's assessment of the legality of a proposed strike is borne out by visual confirmation that the target is in fact lawful and that the requirements of necessity, proportionality, and discrimination are met. ${ }^{58}$ Drones have a distinct advantage on that point since the pilot can observe details through high resolution cameras in order to check whether a target has some indicators such as weapons, explosive devices, etc. to be an object of attack.

Objects can be legitimate targets as well as people if they fulfil certain criteria. The first definition of military objectives dates back to the Hague Rules of Air Warfare, in which it is stated that 'an air bombardment is legitimate only when directed against a military objective, i.e. an objective whereof the total or partial destruction would constitute an obvious military advantage for the belligerent. ${ }^{59}$ Nevertheless, the binding definition of military objectives was codified in article 52(2) of AP-I, which states that 'military objectives are limited to those objects which by their nature, location, purpose, or use make an effective contribution to military action and whose total or partial destruction, capture, or neutralization, in the circumstances ruling at the time, offers a definite military advantage.' Thus, two cumulative criteria must be met in order to render an object as a military target: First, the object should make an effective contribution to military action. Secondly, total or partial destruction, capture, or neutralization of this object should offer military advantage to the belligerent party. However, the determination of military objectives in an armed conflict, which is between a state and a non-state actor, poses significant difficulty on the former, which has a capacity to conduct drone attacks. At this point, it is important to have

57 David Akerson, 'Applying Jus in Bello Proportionally to Drone Warfare' (2014) 16 Oregon Review of International Law $173,206$.

58 UN Doc. A/HRC/ 14/24/Add.6, p. 28-29.

591923 Hague Rules of Air Warfare art 24(1). 
reliable information 'in the circumstances ruling at the time.' If a commander has such information or identifies that an armed group is currently attacking his/her forces through the cameras of a drone, objectives being used by a non-state group, such as barracks or homes, will be held as legitimate targets.

After it is clarified that the targeted object or person is a lawful target, the next step will be the proportionality review if collateral damage is expected. As the Final Report to the Prosecutor by the Committee Established to Review the NATO Bombing Campaign Against the Federal Republic of Yugoslavia indicated, although there is no question on the existence of the principle, the main questions are what it means and how it will be applied to drone attacks. ${ }^{60}$ For this reason, the focus will be on 'military advantage' and 'collateral damage' and how they can be applied to drone attacks in the following sections.

\subsubsection{Gaining Military Advantage via Drone Attacks}

As indicated above, if it is expected that directing attacks against lawful targets may cause collateral damage, anticipated military advantage must justify it. However, if there is no risk of collateral damage occurring, it is not necessary to determine whether to take the principle of proportionality into consideration. Consider a military base which is completely isolated from the civilian settlements; the attacking party does not need to make any proportionality calculation as the damage would exclusively be limited to lawful targets.

The advantage must be concrete and direct. In other words, it should not be hardly perceptible and be expected to be obtained in the long term. Rather, it should be substantial and relatively close. ${ }^{61}$ Concreteness indicates that the advantage must be 'real or tangible, definable, and quantifiable,' and 'mere hope, speculation, and hypotheticals' or 'remote advantages to be gained at some unknown time in the future' must be disregarded. ${ }^{62}$ Directness requires that the advantage should occur without 'intervening condition or agency. ${ }^{63}$

60 William J Fenrick, ‘Applying IHL Targeting Rules to Practical Situations: Proportionality and Military Objectives' (2009) 27 Windsor Yearbook of Access to Justice 271, 278; 'Final Report to the Prosecutor by the Committee Established to Review the NATO Bombing Campaign Against the Federal Republic of Yugoslavia' (hereinafter 'The NATO Bombing Report') para $48<$ https://www.icty.org/x/file/Press/nato061300.pdf > accessed 5 May 2020.278; \uc0 $\backslash \backslash$ u8216 \{\} Final Report to the Prosecutor by the Committee Established to Review the NATO Bombing Campaign Against the Federal Republic of Yugoslavia\luc0 $\backslash$ u 8217\{\} para $48<$ https://www.icty.org/en/press/final-report-prosecutor-committeeestablished-review-nato-bombing-campaign-against-federal> accessed 20 December 2019.","plainCitation":"William J Fenrick, 'Applying IHL Targeting Rules to Practical Situations: Proportionality and Military Objectives' (2009

61 Yves Sandoz, Christophe Swinarski and Bruno Zimmermann (eds), Commentary on the Additional Protocols of 8 June 1977 to the Geneva Conventions of 12 August 1949 (ICRC 1987) para 2209.

62 Laurent Gisel, 'The Rules Governing the Conduct of Hostilities under International Humanitarian Law' (ICRC and Université Laval 2016) International Expert Meeting Report 17; Commentary on the HPCR Manual on International Law Applicable to Air and Missile Warfare (Program on Humanitarian Policy and Conflict Research at Harvard University 2010) 92 ('Commentary on the HPRC Manual'); International Law Association Study Group on the Conduct of Hostilities in the 21 st Century, 'The Conduct of Hostilities and International Humanitarian Law: Challenges of 21st Century Warfare' (2017) 93 International Law Studies 323, 365.

63 International Law Association Study Group on the Conduct of Hostilities in the 21st Century (n 62 ) 344. 
The advantage should be military in nature, and merely political, psychological, economic, financial, social, or moral advantages cannot be included in proportionality calculations. ${ }^{64}$ However, this should not be interpreted in neither a narrow nor broad way. As stated in the Commentary to Additional Protocols, anticipating military advantage just from 'ground gained' operations or via 'annihilating or weakening the enemy armed forces' cannot be applicable to today's conflicts while considering the changing nature of wars. ${ }^{65}$ Drones are especially used against non-state actors, and those actors, such as terrorist organisations, generally do not aim to gain ground in their operations but only aim to cause panic among civilians. Nevertheless, accepting war-sustaining objects, such as the oil industry, as lawful targets since they contribute to the military effort of enemy in an indirect way is an important example of broad interpretation. ${ }^{66}$ It has been criticized by Dinstein because 'almost every civilian activity might be construed by the enemy as indirectly sustaining the war effort' owing to this approach. ${ }^{67}$ According to him, while construing lawful targets, it is important to have a 'proximate nexus' between an object and military action. ${ }^{68}$ Thus, from the perspective of this article, a military advantage should be understood as 'any consequence of an attack which directly enhances friendly military operations or hinders those of the enemy. ${ }^{69}$

Andreson offers three variables that should be considered while assessing anticipated military advantage;

'First, the anticipated military advantage must be measured in terms of the value of eliminating the target in question. If, say, the target is Hitler and the data show that killing him will likely shorten the conflict considerably and save hundreds of thousands of lives, then killing him will have very significant military advantage. Second, the anticipated military advantage must be adjusted for likelihood of success. If the advantage of killing Hitler by aerial bombardment during WWII would have been great, but the likelihood of success miniscule, then the assessment of anticipated military advantage must be adjusted accordingly. That is, one cannot assess anticipated military advantage based on the unrealistic presupposition of $100 \%$ success rate for an operation. Third, the anticipated military advantage should be assessed on a scale of anticipated opportunity from unique, or very limited, to highly repeatable. Unique opportunities to strike a military target will have greater military advantage than strike opportunities that are standing or which are anticipated to recur frequently in the future' ${ }^{70}$

64 Commentary on the HPCR Manual on International Law Applicable to Air and Missile Warfare (n 62) 45.

65 Sandoz, Swinarski and Zimmermann (n 61) para 2218.

66 Christopher Markham and Michael Schmitt, 'Precision Air Warfare and the Law of Armed Conflict' (2013) 89 International Law Studies 669, 677.

67 Yoram Dinstein, The Conduct of Hostilities under the Law of International Armed Conflict (Cambridge University Press 2004) 87.

68 ibid.

69 Commentary on the HPCR Manual on International Law Applicable to Air and Missile Warfare (n 62) 45.

70 Joshua Andreson, 'Challenging the Perplexity over Jus in Bello Proportionality' (2014) 7 European Journal of Legal Studies 19, 31-32. 
Hence, those three variables, which are the value of target, the likelihood of success, and the uniqueness of the opportunity, should be considered by an attacker in the planning stage of a drone strike.

While assessing military advantage, an attack should be assessed as a whole and not be isolated nor should particular parts of it. ${ }^{71}$ As stated by Fenrick and approved by declarations of numerous states, proportionality reviews cannot be made on neither a 'bullet-by-bullet basis' nor on 'the basis of attacks on individual military objectives. ${ }^{72}$ As emphasized in the Commentary on the HPRC Manual;

'Aerial attacks are often conducted by multiple military aircraft, in which case it would be improper to consider the impact of each single sortie in isolation. It is rather necessary to assess the overall mission. To consider military advantage in light of the "attack as a whole" has also other aspects. One example could be a contemplated series of attacks against a number of bridges across the same river when they are in proximity to each other. Although the first attack on one of these bridges might appear to yield only a limited military advantage, considering that the enemy can still use the remaining bridges, the military advantage will become apparent once subsequent attacks against the other bridges take place'. ${ }^{73}$

On the other hand, military advantage cannot be construed by linking it to the 'full context of a war strategy' 74 of a belligerent party since interpreting military

71 Henckaerts and Doswald-Beck (n 43) 49.

72 William J. Fenrick, 'Targeting and Proportionality during the NATO Bombing Campaign against Yugoslavia' (2001) 12 European Journal of International Law 489, 499; Henckaerts and others (n 50) 49.in particular to the requirement to limit incidental civilian casualties. There are no such things as error-free wars or casualty-free wars. It appears, however, that NATO classified a wider range of objects as military objectives than has traditionally been the case, in particular the RTS broadcasting station headquarters in Belgrade. It also appears that some earlier bombing campaigns (the 1972 'Linebacker 2 ' campaign against North Vietnam which was conducted at the dawn of the era of precision weapons is an example

73 Commentary on the HPCR Manual on International Law Applicable to Air and Missile Warfare (n 62) 93.

74 US Department of Defence, Law of War Manual (hereinafter 'DoD Manual') 5.12.2.1; US Department of Army, Insurgencies and Countering Insurgencies FM 3-24/MCWP 3-33.5 13-28.the "Strategic and Operational Context," provides a framework for understanding the environment where a counterinsurgency exists. Part one consists of chapters one through three.Part two, "Insurgencies," provides a doctrinal framework for understanding an insurgency. Part two consists of chapters four and five. Part three, "Counterinsurgencies," describes how to plan and execute operations to enable a host nation to defeat an insurgency.Chapter 1, "Understanding the Strategic Context," answers the questions of how and why U.S. forces might get involved in a counterinsurgency. Chapter 1 highlights that there are many different ways U.S. forces could counter an insurgency and that there are a range of various contexts in which an insurgency can occur. Chapter 2, "Understanding an Operational Environment," provides context for an operational environment where an insurgency might be occurring. Chapter 3, "Culture," describes the role of culture in counterinsurgency operations. Understanding culture is essential in any effort to support a counterinsurgency effort. Culture is of unique importance in understanding an operational environment.Chapter 4, "Insurgency Prerequisites and Fundamentals," provides doctrine for understanding the prerequisites of an insurgency and the root causes that allow an insurgency to keep and gain legitimacy. Chapter 5, "Insurgency Threat Characteristics," provides doctrine for understanding the threat characteristics of an insurgency.Chapter 6, "Command and Control and Mission Command," provides doctrine for executing command and control under the philosophy of mission command. In a counterinsurgency effort, many units may perform many different tasks in decentralized operations. Understanding decentralized operations and ensuring these units are meeting the overall commander's intent is essential for successful counterinsurgency operations.Chapter 7, "Planning and Operational Considerations," provides guidance on how commanders and staffs can work from conceptual planning to detailed planning in counterinsurgency operations. Chapter 8 , "Intelligence," provides considerations for intelligence in counterinsurgency. Because understanding the environment is essential in counterinsurgency, intelligence facilities successful operations. Chapter 9, "Direct Approaches to Counter an Insurgency," provides guidance on how the Army and the Marine Corps directly counter an insurgency at the operational and tactical level. The operational philosophy behind the direct approach is shape-clear-hold-build-transition. Chapter 10, "Indirect Methods for Countering Insurgencies," provides a framework for working with and through a host nation. While the U.S. may provide the primary counterinsurgent forces, it may also 
advantage in such a way may lead to legitimizing all drone attacks, whether they cause 'excessive' damage or not. It must be foreseeable while a reasonable commander is planning the mission and is limited to the impact of attacks on the 'enemy's military tactical or operational level. ${ }^{75}$

There is a discussion on whether accepting force protection is a part of military advantage or not. Some countries, such as the USA, Canada, Australia, and New Zealand, and some scholars accept the security of the attacking forces as a part of military advantage. ${ }^{76}$ However, another approach defends not including it in proportionality calculations by taking articles 48 and 51(1) of AP-I, which regulate civilian protection, into consideration in order to abstain from undermining civilian protection. ${ }^{77}$ From the perspective of the present author, first, this issue should be examined in a contextual basis in a general manner. If there is a threat from an imminent or ongoing attack to armed forces, it would be lawful to count force protection into the proportionality analysis. ${ }^{78}$ Second, even if there is an imminent threat to one's own forces, feasible protections should be taken in order to reduce collateral damage. ${ }^{79}$ Third, this scenario cannot occur in attacks conducted by armed drones. An attacking party who uses drones already refrains from risking their troops, and there is no direct threat against a person who remotely controls an armed drone. A party can use more drones in order to reduce risks imposed on their troops, but this should be evaluated under precautions, not proportionality. Even if operators are proximate to the battlefield, they cannot claim to protect themselves because the nature of remote warfare gives them a chance to conduct an attack away from the battlefield. While being proximate to the battlefield, they have already accepted the risks which they will face, and those risks should not be passed onto civilians. For this reason, a party who conducts drone attacks can never legitimize excessive collateral damage by claiming force protection as a military advantage.

work indirectly through the host nation. There are also important indirect enablers.Chapter 11, "Working with Host-Nation Forces," provides a foundation for understanding how security cooperation efforts are integrated into a counterinsurgency effort. Whether U.S. forces are, for a time, the primary counterinsurgent forces or they are working indirectly through a host nation, enabling the host nation through security cooperation activities is essential.Chapter 12, "Assessments," provides doctrine for understanding how a counterinsurgency environment changes and determining if counterinsurgent actions are having an effect on achieving the desired end state. Chapter 13, "Legal Considerations" provides some legal considerations that are important for commanders and staffs to consider in all counterinsurgency operations.","langua ge":"English","number-of-pages":"194","source":"Amazon","title":"Insurgencies and Countering Insurgencies FM 3-24/ MCWP 3-33.5","author":[\{"family":"US Department of the Army","given":""\}]\}\}],"schema":"https://github.com/ citation-style-language/schema/raw/master/csl-citation.json"\}

75 Commentary on the HPCR Manual on International Law Applicable to Air and Missile Warfare (n 62) 93; Ryan Christian Else, 'Proportionality in the Law of Armed Conflict: The Proper Unit of Analysis for Military Operations' (2010) 5 University of St. Thomas Journal of Law and Public Policy 195, 211.

76 Henckaerts and others (n 50) 50; A. P. V. Rogers, Law on the Battlefield (Manchester University Press 1996) 17.

77 Gisel (n 62) 24.

78 ibid.

79 Rebecca J Barber, 'The Proportionality Equation: Balancing Military Objectives with Civilian Lives in the Armed Conflict in Afghanistan' (2010) 15 Journal of Conflict and Security Law 467, 484. 


\title{
2.2.3. Avoiding 'Excessive' Collateral Damage via Drone Attacks
}

\subsubsection{Collateral Damage}

The term 'collateral' derives from the Latin col- (together with) and later- (side), and it is defined in the Oxford Dictionary as '[1]ying aside from the main subject, line of action, issue, purpose, etc.; side-; subordinate, indirect. ${ }^{90}$ In terms of the LOAC, collateral damage indicates an 'incidental loss of civilian life, injury to civilians, and damage to civilian objects or other protected objects or a combination thereof, caused by an attack on a lawful target. ${ }^{91}$ In other words, collateral damage, which is also known as incidental damage, unavoidably and unintentionally happens to civilian people and property while conducting an attack against a legitimate target. ${ }^{82}$ However, it 'does not include inconvenience, irritation, stress, fear, or other intangible effects occurring on the civilian population. ${ }^{83}$

The extent of collateral damage depends on various factors which are stated in the Commentary to Additional Protocols as;

\begin{abstract}
'the location of civilian population and objects (possibly within or in the vicinity of a military objective), the terrain (landslides, floods, etc.), accuracy of the weapons used (greater or lesser dispersion, depending on the trajectory, the range, the ammunition used, etc.), weather conditions (visibility, wind, etc.), the specific nature of the military objectives concerned (ammunition depots, fuel reservoirs, main roads of military importance at or in the vicinity of inhabited areas, etc.), technical skill of the combatants (random dropping of bombs when unable to hit the intended target), ${ }^{84}$
\end{abstract}

It also contains both direct and indirect effects of an attack. The former type of effects occurs immediately as a result of the attack, and they are not altered by intervening events or mechanisms. ${ }^{85}$ However, the latter type of effects occurs as the delayed or displaced second, third, and higher order results of the attack, and they are consequences of intermediate events and mechanisms. ${ }^{86}$ As stated in the UK Joint Service Manual, if it is expected for burning oil to leak into a civilian area after a remote attack and to cause excessive collateral damage, this will be regarded as an indiscriminate attack ${ }^{87}$ Although there is no agreement on what extent these indirect effects must be taken into consideration, it should be stated that indirect effects which

\footnotetext{
80 https://www.oed.com/view/Entry/36237?redirectedFrom=collateral\#eid

81 HPRC Manual art 1(1).

82 The Judge Advocate General's Legal Center and School, Operational Law Handbook (2015) 14.

83 Commentary on the HPCR Manual on International Law Applicable to Air and Missile Warfare (n 62) 34.

84 Sandoz, Swinarski and Zimmermann (n 61) para 2212

85 Joint Targeting School Student Guide (Joint Targeting School 2017) 15.

86 ibid.

87 UK Ministry of Defence, The Joint Service Manual of the Law of Armed Conflict (The Joint Doctrine and Concepts Centre 2004) 5.33.4.
} 
are too remote or not reasonably foreseeable shall not be included in proportionality calculations. ${ }^{88}$

It is uncertain to render whether inflicting harm upon medical or religious personnel of armed forces as collateral damage or not. The opinion which does not count those harmed as collateral damage can be supported by two arguments. First, according to article 43(1) of the AP-I, '[t]he armed forces of a Party to a conflict consist of all organized armed forces, groups, and units which are under a command responsible to that Party for the conduct or its subordinates.' Because those medical and religious personnel are part of the armed forces, it can be claimed that attacking them might not be accepted as collateral damage. Also, articles 51(5)(b), 57(2)(a) (iii), and 57(2)(b), which regulate the principle of proportionality, only include 'loss of civilian life, injury to civilians, and damage to civilian objects' within the ambit of collateral damage. ${ }^{89}$ This idea can be supported by practices of some states. It is stated in the DoD Manual that the prohibition of excessive damage does not involve causing incidental harm against protected military personnel and objects even if they cannot be subject to direct attacks. ${ }^{90}$ Because those personnel are proximate to combatant elements, they are rendered to have accepted the risks of war and cannot be included in a proportionality assessment, but an attacking party should take all feasible precautions to mitigate risks deriving from military operations towards those personnel. ${ }^{91}$

On the other hand, such an approach is not consistent with the purposes of the LOAC. First of all, even though military and religious personnel are part of the armed forces, article 43(2) of AP-I clearly states they are not 'combatants.' Secondly, in the Nuclear Weapons Advisory Opinion, the ICJ did not limit collateral damage to civilians but also included environmental considerations in the proportionality review. ${ }^{92}$ Therefore, it is clear that collateral damage is not limited to civilian lives and objects in practice, but it also involves other considerations. As stated in the Explanation of the San Remo Manual, 'in practice the rule extends to damage or injury caused to all persons or objects that may not be directly attacked, and therefore this definition has included other protected persons (for example, the wounded, sick, shipwrecked), all objects that are not military objectives, and the natural environment' even though the articles only speak about civilians. ${ }^{93}$ Lastly, the ICRC takes the same position in the updated commentary of the Geneva Conventions by arguing that the

88 Commentary on the HPCR Manual on International Law Applicable to Air and Missile Warfare (n 62) 92.

89 Ian Henderson, The Contemporary Law of Targeting : Military Objectives, Proportionality, and Precautions in Attack under Additional Protocol I (Martinus Nijhoff Publishers 2009) 206.

90 US Department of Defence (n 74) para 5.10.1.2.

91 ibid 7.8.2.1.

92 Nuclear Weapons Advisory Opinion para. 30.

93 Louise Doswald-Beck (ed), San Remo Manual on International Law Applicable to Armed Conflicts at Sea (Cambridge University Press 1995) 87. 
duty to 'respect,' stated in article 24 of Geneva Convention I and article 36 of Geneva Convention II, obliges belligerent parties to comply with 'the duties of abstention, such as not to attack medical and religious personnel (be it directly, indiscriminately, or in violation of the principle of proportionality). ${ }^{94}$ Therefore, to ensure the respect of such personnel also requires considering them as a part of the proportionality review. Hence, the present author considers those personnel should be taken into account by not focusing on the wording of the article but by approaching the issue through teleological interpretation. Since inflicting harm on those people does not provide any military advantage, it is not rational to legitimize those adverse effects.

Dual-use objects are those used to serve both civilian and military purposes, such as bridges or GPS systems. ${ }^{95}$ It is claimed that civilian objects as defined in Article 52(2) of AP-I are 'all objects which are not military objectives,' and the nature of dual-use object can lead to considering the dual-use object as a military objective, depending on whether it meets the two criteria of being an effective contribution and gaining military advantage by attacking this object. ${ }^{96}$ In line with this opinion, if a drone attack is conducted against such an object, it will not be necessary to make a proportionality calculation. On the other hand, the principle of proportionality necessitates considering all foreseeable damages imposed on the civilian population. ${ }^{97}$ The bridge can be attacked via armed drone if it makes an effective contribution to an enemy's military action. However, even if it is expected to cause small civilian harm through this attack, the damage should be accepted as collateral and taken into consideration. Also, if civilian harm cannot be estimated, the attack must not be initiated.

There is a discussion on whether harming voluntary human shields can be included in the proportionality equation or not. According to Dinstein, voluntary human shields aim to deter enemy attacks; that is why they should be regarded as direct participants and lawful targets. ${ }^{98}$ In comparison to this opinion, it is argued that these people do not direct any violence against enemy combatants which is necessary for accepting someone as direct participant (threshold of harm), and they do not lose their protected status. ${ }^{99}$ The working of the ICRC on the Interpretive Guidance on the Notion of

94 International Committee of the Red Cross, Commentary on the First Geneva Convention: Convention (I) for the Amelioration of the Condition of the Wounded and Sick in Armed Forces in the Field (Cambridge University Press 2016) para 1987; International Committee of the Red Cross, Commentary on the Second Geneva Convention: Convention (II) for the Amelioration of the Condition of Wounded, Sick and Shipwrecked Members of Armed Forces at Sea (Cambridge University Press 2017) para 2462.

95 Maurice Cotter, 'Military Necessity, Proportionality and Dual-Use Objects at the ICTY: A Close Reading of the Prlić et al Proceedings on the Destruction of the Old Bridge of Mostar' (2018) 23 Journal of Conflict and Security Law 283, 297.

96 Françoise J Hampson and Yoram Dinstein, 'Proportionality and Necessity in the Gulf Conflict' (1992) 86 Proceedings of the Annual Meeting (American Society of International Law) 45, 50; Henderson (n 89) 207.

97 Schmitt (n 11) 140.

98 Dinstein (n 68) 130.

99 'Expert Meeting “Targeting Military Objectives”' (University Centre for International Humanitarian Law 2005) 20. 
Direct Participation in Hostilities finds a compromise on this issue. According to the Guidance, if those people cause the prevention of an attack by positioning themselves as physical obstacles, they will be accepted as direct participants, but if their position does not have any detrimental effect on the capacity of the attacker because of the power of weapons used in the attack, such as air strikes, then those persons will not be regarded as direct participants. Thus, causing harm to them will be accepted as collateral damage. ${ }^{100}$ On the other hand, there is no discussion on accepting involuntary human shields as protected persons. ${ }^{101}$ Therefore, if civilians are forced to be human shields, the harms imposed upon them should be accepted as collateral damage. Consequently, drone attacks are air attacks in which powerful weapons are used; hence, causing harm on voluntary or involuntary human shields by using armed drones will be accepted as collateral damage, and if they result in excessive damages, they will be unlawful.

Lastly, if an attacker cannot predict the collateral damage resulting from a drone strike, it should be cancelled or suspended until having reasonable certainty. However, if the attacker took precautions and conducted an attack against a lawful target, he would not bear any responsibility despite the fact that the attack resulted in excessive harm because of an undetermined reason. Moreover, collateral damage should not be understood as a legal tool which legitimizes killing enemy civilians. Parties should 'value the lives of enemy civilians to the same extent that they value the lives of their own civilians and military personnel' because of their dignity as human beings. ${ }^{102}$ However, if there is a reasonable expectation to gain military advantage by causing civilian damage, then collateral damage will come into the scene as an unintentional consequence of a strike which is not excessive in comparison to its advantage.

\subsubsection{Determination of Excessiveness}

The lexical meaning of excessive is ' $[\mathrm{m}]$ ore than is necessary, normal, or desirable; immoderate' ${ }^{103}$ or ' $[t]$ ransgressing the bounds of law, decency, or morality; outrageous, lawless, wrongful. ${ }^{104}$ Belligerent parties always need to calculate whether expected collateral damage is excessive compared to the anticipated military advantage or not.

The two terms 'extensive' and 'excessive' should be distinguished. These terms were used almost interchangeably in the Commentary to Additional Protocols by arguing that an attack shall not cause 'extensive destruction of civilian objects.' ${ }^{105}$

\footnotetext{
100 Melzer (n 51) 56-57.

101 ibid 57 n. 141.

102 Andreson (n 64) 34.

103 https://www.lexico.com/en/definition/excessive

104 https://www.oed.com/view/Entry/65759?redirectedFrom=excessive\#eid

105 Sandoz, Swinarski and Zimmermann (n 61) 2218.
} 
However, AP-I clearly prohibits excessive damage, and the scale of destruction does not make the attack unlawful per se. If the anticipated military advantage is significant enough because of the military value of the lawful target, extensive collateral damage will be justified legally. ${ }^{106}$ As stated by the Eritrean-Ethiopia Commission, although civilian casualties and losses are 'regrettable and tragic consequences of the war,' if it is not proven that they are disproportionate in comparison to their anticipated military advantage, 'they do not in themselves establish liability ... under international law. ${ }^{107}$

While there is no clear rule on how to determine whether the collateral damage is excessive or not, it is stated in the Galic Case that

'In determining whether an attack was proportionate, it is necessary to examine whether a reasonably well-informed person in the circumstances of the actual perpetrator, making reasonable use of the information available to him or her, could have expected excessive civilian casualties to result from the attack' ${ }^{108}$

However, rather than the assessment of every reasonably well-informed person, the NATO Bombing Report suggests determining it by the 'reasonable military commander' criterion by arguing that

\begin{abstract}
'It is unlikely that a human rights lawyer and an experienced combat commander would assign the same relative values to military advantage and to injury to non-combatants. Further, it is unlikely that military commanders with different doctrinal backgrounds and differing degrees of combat experience or national military histories would always agree in close cases. It is suggested that the determination of relative values must be that of the "reasonable military commander." Although there will be room for argument in close cases, there will be many cases where reasonable military commanders will agree that the injury to non-combatants or the damage to civilian objects was clearly disproportionate to the military advantage gained.' ${ }^{109}$
\end{abstract}

On the other hand, Henderson offers to use both of these criteria in a way that assesses the proportionality of an attack by depending it on 'the circumstances of the commander and the information available to him or her' (subjective aspect), but 'the conclusions to be reached on whether collateral damage is expected and whether it is proportional is then based on what a reasonable person would have concluded from that information' (objective aspect). ${ }^{110}$ However, placing a double standard on proportionality makes the principle more relative, which is already unclear enough. Moreover, his suggestion misses the point that the principle of proportionality is 'prospective in nature, so an attacker is obligated to estimate and compare military

106 Commentary on the HPCR Manual on International Law Applicable to Air and Missile Warfare (n 62) 92.

107 Eritrea-Ethiopia Claims Commission, Western Front, Aerial Bombardment and Related Claims-Eritrea's Claims 1, 3, 5, 9-13, 14, 21, 25 \& 26 (Partial Award of 2005) para 97.

108 Prosecutor $v$ Stanislav Galic (Trial Judgement) ICTY-98-29-T (5 December 2003) para 58.

109 The NATO Bombing Report para. 50.

110 Henderson (n 89) 222. 
advantage and civilian harm at the time the attack is contemplated.' ${ }^{111}$ Therefore, the proportionality calculation requires ex ante determination, not ex post. In the targeting process of a person, drone pilots keep two considerations in mind: 'The first would be the likelihood of the particular attack in achieving the goal of elimination. The second would be the military advantage of eliminating that person.' ${ }^{112}$ At this point, even though the remoteness of the perpetrator of a drone attack from the battlefield already allows him/her to determine the principle of proportionality in a more realistic way than those in the theather and allows him/her to render the legality of the decision more reliably, the anticipated result by attackers cannot be certain at all times, and objective criterion cannot be applicable because of the risk of vagueness of the expected result of an attack. Hence, the reasonable commander criterion should be used while assessing the proportionality of drone attacks, and ex ante determination should be made in order to decide its legality.

An important factor when making the determination of the excessiveness of an attack is the urgency to engage a target. While arguing two different types of attacks, Akerson explains that

\begin{abstract}
'Attacks subject to a proportionality review can be broken down into two categories. The first type consists of attacks that are premeditated in nature, decided only after careful consideration of the circumstances. The second type consists of attacks that, given the circumstances, are conducted under exigent circumstances and thus without the same contemplative ability. The second type would include attacks required to eliminate an immediate and serious threat, for example when UAV operators identify a suspected suicide bomber in or heading toward a civilian area'. ${ }^{113}$
\end{abstract}

At this point, the second type of attack would require a more flexible approach in the determination of excessiveness.

There is no difference among civilians while examining the 'excessiveness' of the attack. Therefore, claiming to take 'friendly' and 'neutral' civilians into consideration when deciding on an attack is not applicable in the LOAC. ${ }^{114}$ There is not any difference between civilians who have either friendly or hostile intentions toward the attacking party when deciding the strike and considering the results of it whether they are excessive or not. Moreover, even if a belligerent party does not expect to cause excessive damage by a drone attack against those people but the change of a weapon or a tactic might decrease the level of collateral damage, the attacking party should apply that alternative by considering the benefit to civilians.

111 Akerson (n 57) 185.

112 ibid 195. However, as admitted by Akerson, it is harder to estimate military value of a target in drone attacks comparing with conventional warfare since '[c]onventional warfare involves clear rank and hierarchy; UAV warfare attempts to identify the leadership of irregular fighters that are hiding as and amongst civilians’. See ibid 196.

113 Akerson (n 57) 211.

114 Rogier Bartels, 'Dealing with the Principle of Proportionality in Armed Conflict in Retrospect: The Application of the Principle in International Criminal Trials' (2013) 46 Israel Law Review 271, 303. 
If it becomes obvious that excessive damage will occur and the attack is suspended, this does not change the military status of the target, and the attack might be conducted later when the damage is not disproportionate. As stated by Henderson,

'Whether or not an object is a military objective is assessed against the test in article 52(2) API. Whether an attack on that object in a certain way (eg, by a $2000 \mathrm{lb}$ bomb) will cause disproportionate collateral damage does not affect the object's status as a military objective. Rather, and in accordance with the wording of article 57(2)(a)(iii) API, a party must refrain from deciding to launch the attack if the expected collateral damage would be excessive. For example, the status of a military air traffic control tower in close proximity to civilian hous- ing does not change from not being a military objective if attacked using a $2000 \mathrm{lb}$ unguided bomb to being a military objective if attacked using a $500 \mathrm{lb}$ laser-guided bomb. Rather, the tower's status as a military objective is solely dependant upon the article 52(2) API test. What does change is whether in any given scenario it is lawful to launch a potential attack against the tower'. ${ }^{115}$

Therefore, the reason behind the suspension of an attack should not be confused with the status of an object, and it does not preclude destroying the legitimate target later.

The principle of proportionality and the determination of excessiveness should not be held as a mathematical formula. ${ }^{116}$ Although it is stated that '[f]ifty civilians killed for one suspected combatant killed is a textbook example of a violation of the proportionality principle,' 117 excessiveness cannot be construed as counting the number of civilian and combatant casualties and comparing them with each other. ${ }^{118}$ As stated in the NATO Bombing Report,

'It is much easier to formulate the principle of proportionality in general terms than it is to apply it to a particular set of circumstances because the comparison is often between unlike quantities and values. One cannot easily assess the value of innocent human lives as opposed to capturing a particular military objective.' 119

Hence, excessiveness should be evaluated based on the comparison between two values which are collateral damage and military advantage. The determination of it should be on the basis of the context in which the decision is given, a reasonable military commander criterion, and good faith.

\footnotetext{
115 Henderson (n 89) 198.
}

116 Laurie R Blank, 'A New Twist on an Old Story: Lawfare and the Mixing of Proportionalities' (2010) 43 Case W. Res. J. Int'1 L. 707, 716; Michael Wells-Greco, 'Operation “Cast Lead”: Jus in Bello Proportionality' (2010) 57 Netherlands International Law Review 397, 416.

117 O’Connell (n 3) 24.Barack Obama authorized the CIA to continue President Bush's policy of attacks using unmanned aerial vehicles (UAVs or drones

118 Commentary on the HPCR Manual on International Law Applicable to Air and Missile Warfare (n 44) 92.

119 The NATO Bombing Report para. 48. 


\section{Conclusion}

While new technologies pose significant challenges to international law, they do not preclude the application of the relevant rules. At this point, the use of armed drones and conducting remote attacks has led to many debates in the LOAC. However, those debates do not have a significant impact on how the principles of conduct of hostilities can be applied to those attacks.

In this article, first, the legality of using armed drones was explained. Although there is no clear article in either Geneva Conventions or the Additional Protocols to permit or prohibit the use of drones, they are not illegal per se as weapons. However, it is important to comply with targeting rules to carry out attacks by them. Although the remoteness of the perpetrator might cause him/her to act in a more flexible manner when engaging in lawful targets, this can be prevented by appropriate training programs. Also, it should be stated that both the LOAC and the Human Rights Law govern armed conflicts in parallel to each other, and not only the former but also latter places responsibility on parties. However, the human rights obligations of states are limited to the jurisdictions recognized by belligerent parties.

In the second part, it was clarified that the principle of proportionality obliges belligerent parties to conduct their attacks against lawful targets in a way that it will not result in excessive civilian harm by trying to gain military advantage. Although a weaker side of an armed conflict might try to hide their members by mixing them within a civilian population, the responsibility of an attacking party does not go beyond what is known by it at the relevant time. At this point, drones give an opportunity to operators to get better intelligence than those on the ground. After the best intelligence is obtained, the attacking party can initiate an attack against a target. However, it cannot be concluded that any civilian harm is unlawful under the LOAC even if the best intelligence is obtained. Whilst a perpetrator conducts a drone strike by being aware of the fact that some civilians will be harmed as a result of the attack, he/she expects a certain level of military advantage from it. Although some factors such as the urgency of an attack or the value of a target have an impact on the level of the balance between military advantage and collateral damage, this two-sided evaluation cannot be disproportionate. For this reason, the calculation of excessiveness should be considered by a reasonable military commander while planning, approving, or executing an attack, and it should be assessed in good faith.

Peer-review: Externally peer-reviewed.

Conflict of Interest: The author has no conflict of interest to declare.

Grant Support: The author declared that this study has received no financial support.

Hakem Değerlendirmesi: Dış bağımsız.

Çıkar Çatışması: Yazar çıkar çatışması bildirmemiştir.

Finansal Destek: Yazar bu çalışma için finansal destek almadığını beyan etmiştir. 


\section{Bibliography/Bibliyografya}

\section{Primary Sources}

Treaties, Manuals

'Declaration (IV,1), to Prohibit, for the Term of Five Years, the Launching of Projectiles and Explosives from Balloons, and Other Methods of Similar Nature. The Hague, 29 July 1899.' $<$ https://ihl-databases.icrc.org/applic/ihl/ihl.nsf/Article.xsp?action=openDocument\&documen tId=C372920FFD61039AC12563CD00516126> accessed 30 January 2020.

Protocol Additional to the Geneva Conventions of 12 August 1949, and relating to the Protection of Victims of International Armed Conflicts (adopted 8 June 1977, entered into force 7 December 1978) 1125 UNTS 3

Protocol Additional to the Geneva Conventions of 12 August 1949 and relating to the Protection of Victims of Non-International Armed Conflicts (adopted 8 June 1977, entered into force 7 December 1978) 1125 UNTS 609

Protocol on Prohibitions or Restrictions on the Use of Mines, Booby-Traps and Other Devices (entered into force 2 December 1983) 1342 UNTS 168, 19 ILM 1529, as amended 3 May 1996, 35 ILM 1206

HPCR Manual on International Law Applicable to Air and Missile Warfare (Bern, 15 May 2009)

\section{Cases}

Alejandre et al. $v$ Cuba Case No. 11.589 (IACiHR 29 September 1999)

Al-Saadoon and Mufdhi v The United Kingdom App no. 61498/08 (ECtHR 30 June 2009)

Application of the Convention on the Prevention and Punishment of the Crime of Genocide (Croatia v. Serbia) (Judgment) [2015] ICJ Rep 3

Bankovic and others v Belgium and 16 other Contracting States App No. 52207/99 (ECtHR 12 December 2001)

Case Concerning Armed Activities on the Territory of the Congo (Democratic Republic of the Congo v. Uganda) (Judgment) [2005] ICJ Rep 168

Hassan v United Kingdom App no 29750/09 (ECtHR 16 September 2014)

Legal Consequences of the Construction of a Wall in the Occupied Palestinian Territory (Advisory Opinion) [2004] ICJ Rep 136

Isayeva v Russia App no 57950/00 (ECtHR 24 February 2005)

Loizidou v Turkey App no. 15318/89 (ECtHR 23 March 1995)

Military and Paramilitary Activities in and against Nicaragua (Nicaragua v. United States of America) (Judgment) [1984] ICJ Rep 392

Prosecutor v Dragoljub Kunarac, Radomir Kovac and Zoran Vukovic (Judgement) ICTY-96-23 \& ICTY-96-23/1-A (12 June 2002)

Prosecutor v Dusko Tadic (Decision on the Defence Motion for Interlocutory Appeal on Jurisdiction) ICTY-94-1 (2 October 1995)

Prosecutor v Dusko Tadic (Judgment) ICTY-94-1-T (7 May 1997)

Prosecutor v Dusko Tadic (Appeal Judgement) ICTY-94-1-A (15 July 1999) 
Prosecutor v Germain Katanga (Judgement pursuant to article 74 of the Statute) ICC- 01/04-01/07 (7 March 2014)

Prosecutor v Jean-Paul Akayesu (Trial Judgment) ICTR-96-4-T (2 September 1998)

Prosecutor v Jean-Pierre Bemba Gombo (Judgment pursuant to Article 74 of the Statute) ICC01/05-01/08 (21 March 2016)

Prosecutor v Stanislav Galic (Trial Judgement) ICTY-98-29-T (5 December 2003)

Prosecutor v Zoran Kupreskic and others (Judgement) ICTY-95-16-T (14 January 2000)

\section{Other Legal Documents}

Commission E-EC, Western Front, Aerial Bombardment and Related Claims-Eritrea's Claims 1, 3, 5, 9-13, 14, 21, 25 \& 26 (Partial Award of 2005)

UNHRC, Report of the Special Rapporteur on Extrajudicial, Summary or Arbitrary Executions, Philip Alston, Addendum, Study on Targeted Killings, UN Doc. A/HRC/ 14/24/Add.6, (May 28, 2010)

\section{Secondary Sources}

\section{Books, Book Chapters, Articles}

Akerson D, 'Applying Jus in Bello Proportionally to Drone Warfare' (2014) 16 Oregon Review of International Law 173

Andreson J, 'Challenging the Perplexity over Jus in Bello Proportionality' (2014) 7 European Journal of Legal Studies 19

Barber RJ, 'The Proportionality Equation: Balancing Military Objectives with Civilian Lives in the Armed Conflict in Afghanistan' (2010) 15 Journal of Conflict and Security Law 467

Bartels R, 'Dealing with the Principle of Proportionality in Armed Conflict in Retrospect: The Application of the Principle in International Criminal Trials' (2013) 46 Israel Law Review 271

Blank LR, 'A New Twist on an Old Story: Lawfare and the Mixing of Proportionalities' (2010) 43 Case W. Res. J. Int'1 L. 707

Borelli S, 'The (Mis)-Use of General Principles of Law: Lex Specialis and the Relationship Between International Human Rights Law and the Laws of Armed Conflict', General Principles of LawThe Role of the Judiciary (Springer 2015)

Commentary on the HPCR Manual on International Law Applicable to Air and Missile Warfare (Program on Humanitarian Policy and Conflict Research at Harvard University 2010)

Commission E-EC, Western Front, Aerial Bombardment and Related Claims-Eritrea's Claims 1, 3, 5, 9-13, 14, 21, 25 \& 26 (Partial Award of 2005)

Cotter M, 'Military Necessity, Proportionality and Dual-Use Objects at the ICTY: A Close Reading of the Prlić et al. Proceedings on the Destruction of the Old Bridge of Mostar' (2018) 23 Journal of Conflict and Security Law 283

Dinstein Y, The Conduct of Hostilities under the Law of International Armed Conflict (Cambridge University Press 2004)

Doswald-Beck L (ed), San Remo Manual on International Law Applicable to Armed Conflicts at Sea (Cambridge University Press 1995) 
E. W. P, 'Developing and Integrating Unmanned Systems for Military Operations' in Ronan Doaré and others (eds), Robots on the Battlefield Contemporary Perspectives and Implications for the Future (Combat Studies Institute Press 2014)

Else RC, 'Proportionality in the Law of Armed Conflict: The Proper Unit of Analysis for Military Operations' (2010) 5 University of St. Thomas Journal of Law and Public Policy 195

'Expert Meeting “Targeting Military Objectives"' (University Centre for International Humanitarian Law 2005)

Fenrick WJ, 'The Rule of Proportionality and Protocol I in Conventional Warfare' (1982) 98 Military Law Review 91

_ ' 'Targeting and Proportionality during the NATO Bombing Campaign against Yugoslavia' (2001) 12 European Journal of International Law 489

- 'Applying IHL Targeting Rules to Practical Situations: Proportionality and Military Objectives' (2009) 27 Windsor Yearbook of Access to Justice 271

Gettinger D, The Drone Databook (The Center for the Study of the Drone at Bard College 2019)

Gisel L, 'The Rules Governing the Conduct of Hostilities under International Humanitarian Law' (ICRC and Université Laval 2016) International Expert Meeting Report

Hampson FJ, 'The Principle of Proportionality in the Law of Armed Conflict' in S Perrigo and J Whitman (eds), The Geneva Conventions Under Assault (Pluto Press 2010)

Hampson FJ and Dinstein Y, 'Proportionality and Necessity in the Gulf Conflict' (1992) 86 Proceedings of the Annual Meeting (American Society of International Law) 45

Heller KJ, “'One Hell of a Killing Machine” Signature Strikes and International Law' (2013) 11 Journal of International Criminal Justice 89

Henckaerts J-M and Doswald-Beck L (eds), Customary International Humanitarian Law (Cambridge University Press 2005)

Henderson I, The Contemporary Law of Targeting : Military Objectives, Proportionality, and Precautions in Attack under Additional Protocol I (Martinus Nijhoff Publishers 2009)

International Committee of the Red Cross, Commentary on the First Geneva Convention: Convention (I) for the Amelioration of the Condition of the Wounded and Sick in Armed Forces in the Field (Cambridge University Press 2016)

- Commentary on the Second Geneva Convention: Convention (II) for the Amelioration of the Condition of Wounded, Sick and Shipwrecked Members of Armed Forces at Sea (Cambridge University Press 2017)

International Law Association Study Group on the Conduct of Hostilities in the 21st Century, 'The Conduct of Hostilities and International Humanitarian Law: Challenges of 21st Century Warfare' (2017) 93 International Law Studies 323

Joint Targeting School Student Guide (Joint Targeting School 2017)

Markham C and Schmitt M, 'Precision Air Warfare and the Law of Armed Conflict' (2013) 89 International Law Studies 669

Melzer N, Interpretive Guidance on the Notion of Direct Participation in Hostilities under International Humanitarian Law (International Committee of the Red Cross 2009)

- Human Rights Implications of the Usage of Drones and Unmanned Robots in Warfare (European Parliament 2013) 
O'Connell ME, 'Unlawful Killing with Combat Drones: A Case Study of Pakistan, 2004-2009' (Social Science Research Network 2009) <https://papers.ssrn.com/abstract=1501144> accessed 5 May 2020

Rogers APV, Law on the Battlefield (Manchester University Press 1996)

Sandoz Y, Swinarski C and Zimmermann B (eds), Commentary on the Additional Protocols of 8 June 1977 to the Geneva Conventions of 12 August 1949 (ICRC 1987)

Schmitt MN, 'Drone Attacks under the Jus Ad Bellum And Jus in Bello: Clearing the "Fog of Law" in MN Schmitt, Louise Arimatsu and T McCormack (eds), Yearbook of International Humanitarian Law - 2010, vol 13 (T M C Asser Press 2011)

—, 'Air Warfare' in Andrew Clapham and Paola Gaeta (eds), The Oxford Handbook of International Law in Armed Conflict (Online 2014)

Schmitt MN and Thurnher JS, 'Out of the Loop: Autonomous Weapon Systems and the Law of Armed Conflict' (2013) 4 Harvard National Security Journal 231

The Judge Advocate General's Legal Center and School, Operational Law Handbook (2015)

UK Ministry of Defence, The Joint Service Manual of the Law of Armed Conflict (The Joint Doctrine and Concepts Centre 2004)

—, Unmanned Aircraft Systems (Development, Concepts and Doctrine Centre 2017)

US Department of Defence, Law of War Manual (2015)

US Department of the Army, Insurgencies and Countering Insurgencies FM 3-24/MCWP 3-33.5

Wells-Greco M, 'Operation “Cast Lead": Jus in Bello Proportionality' (2010) 57 Netherlands International Law Review 397

\section{Online Documents}

'Final Report to the Prosecutor by the Committee Established to Review the NATO Bombing Campaign Against the Federal Republic of Yugoslavia | International Criminal Tribunal for the Former Yugoslavia' < https://www.icty.org/x/file/Press/nato061300.pdf> accessed 5 May 2020

O'Connell ME, 'Unlawful Killing with Combat Drones: A Case Study of Pakistan, 2004-2009' (Social Science Research Network 2009) SSRN Scholarly Paper ID $1501144<$ https://papers. ssrn.com/abstract $=1501144>$ accessed 1 January 2020 
